$\begin{array}{rr}\text { JURNAL } & \text { Volume } 16, \text { Nomor } 1, \text { Januari } 2020 \\ \text { FIT(1) HALOGI } & \text { Halaman } 1-8 \\ \text { I N D O N E S I } & \text { DOI: } 10.14692 / \text { jfi. } 16.1 .1-8\end{array}$

\title{
Deteksi dan Identifikasi Nematoda Puru Akar (Meloidogyne spp.) pada Tanaman Bit Menggunakan Metode DNA Barcoding
}

\author{
Detection and Identification Root Knot Nematode (Meloidogyne spp.) \\ in Sugar Beet Using DNA Barcoding Method
}

\author{
Ni Wayan Kartika Pratiwi, Fawwaz El Auly, Rosyid Amrulloh, Fitrianingrum Kurniawati* \\ Institut Pertanian Bogor, Bogor 16680
}

\begin{abstract}
ABSTRAK
Identifikasi nematoda berdasarkan karakter morfologi memerluan ketelitian tinggi dan perlu didukung hasil identifikasi secara molekuler. Salah satu metode identifikasi molekuler ialah dengan DNA barcode. DNA barcode merupakan identifikasi molekuler dengan menggunakan gen cytochrome oksidase sub unit 1 (CO1). Penelitian ini bertujuan untuk mengidentifikasi NPA yang berasosiasi pada tanaman bit berdasarkan PCR dan perunutan nukleotida gen CO1 Meloidogyne. Sampel umbi bit diperoleh dari lahan pertanian yang terletak di Kecamatan Cipanas, Kabupaten Cianjur, Jawa Barat. Pengambilan sampel dilakukan dengan metode purposive sampling. Identifikasi morfologi dengan mengamati pola perineal NPA betina. Identifikasi molekuler meliputi ekstraksi, amplifikasi, visualisasi DNA, analisis peruntutan nukleotida dan filogenetika. Hasil pengamatan pola perineal secara morfologi didapatkan spesies $M$. incognita dan $M$. arenaria. Amplifikasi DNA yang dilakukan menggunakan primer spesifik CO1SIF (5'-GCCTGCATTTGGTTAG-'3) dan CO1SIR (5'-TCAAACCAGTCCT-‘3), CO1SAF (5'-GGGTACTGGATGAACATTA-'3) dan CO1SAR (5'-ACTTCAGGATGACCAAA-‘3) berhasil mendapatkan pita DNA berukuran \pm 360 untuk $M$. arenaria dan \pm 326 untuk M. incognita. Hasil sekuensing menunjukkan bahwa isolat $M$. incognita asal Indonesia berkerabat dekat dengan isolat M. incognita asal Cina, Amerika Serikat, Vietnam, dan Inggris dengan tingkat homologi $100 \%$. Hasil analisis filogenetika menunjukkan bahwa $M$. incognita Indonesia masih satu kelompok dengan $M$. incognita asal Cina, Amerika Serikat, Vietnam dan Inggris. Adapun isolat M. arenaria berkerabat dekat dengan isolat M. arenaria asal Argentina dan Amerika Serikat dengan tingkat homologi $100 \%$. Hasil analisis filogenetika menunjukkan bahwa $M$. arenaria asal Indonesia masih satu kelompok dengan $M$. arenaria asal Argentina dan Amerika Serikat.
\end{abstract}

Kata kunci: amplifikasi DNA, filogenetika, gen CO1, homologi, sekuensing

\section{ABSTRACT}

Nematode identification based on morphological characters requires high accuracy and needs to be supported by molecular identification results. One method of molecular identification is DNA barcodes. DNA barcode is a molecular identification using the cythochrome oxidase sub unit 1 (CO1) gene. This study aims to identify NPA associated with beetroot based on PCR and Meloidogyne CO1 nucleotide gene sequencing. Beetroot samples were obtained from agricultural land located in Cipanas District, Cianjur Regency, West Java. Sampling was done by purposive sampling method. Morphological identification by observing the perineal pattern of female NPA. Molecular identification includes extraction, amplification, DNA visualization, nucleotide and phylogenetic analysis. Morphological perineal pattern observations obtained $M$. incognita and $M$. arenaria species. DNA amplification was

*Alamat penulis korespondensi: Departemen Proteksi Tanaman, Fakultas Pertanian, Institut Pertanian Bogor. Jalan Kamper, Kampus IPB Darmaga, Bogor 16680

Tel: 0251-8621267, Faks: 0251-8621267, Surel: fitrianingrum@apps.ipb.ac.id 
carried out using CO1SIF (5'-GCCTGCATTTGGTTAG-‘3) and CO1SIR (5'-TCAAACCAGTCCT-‘3), CO1SAF (5'-GGGTACTGGATGAACATTA-'3) and CO1SAR (5'-ACTTCAGGATGACCAAA-‘3). DNA amplification succeeded in getting a DNA band measuring \pm 360 for $M$. arenaria and \pm 326 for $M$. incognita. The sequencing results showed that $M$. incognita isolates from Indonesia were closely related to $M$. incognita isolates from China, US, UK, and Vietnam with a $100 \%$ homology level. The results of the phylogeny analysis showed that $M$. incognita Indonesia was still in the same group as $M$. incognita from China, US, UK, and Vietnam. $M$. arenaria isolates were closely related to $M$. arenaria isolates from Argentina and US with a homology level of $100 \%$. The results of phylogenetic analysis showed that $M$. arenaria from Indonesia was still in the same group as $M$. arenaria from Argentina and US.

Key words: CO1 gene, DNA amplification, homology, phylogenetics, sequencing

\section{PENDAHULUAN}

Identifikasi terhadap nematoda puru akar (NPA) saat ini umumnya dilakukan berdasarkan karakter morfologi dan molekuler dengan menggunakan ITS rDNA. Rahman et al (2018) melaporkan bahwa identifikasi nematoda berdasarkan karakter morfologi memerluan ketelitian tinggi dan perlu didukung hasil identifikasi molekuler menggunakan metode polymerase chain reaction ( $\mathrm{PCR}$ ). Identifikasi berdasarkan karakter morfologi hanya dapat dilakukan oleh peneliti ahli dan kompeten dalam bidang nematologi.

Teknik identifikasi nematoda berdasarkan karakter morfologi perlu diklarifikasi menggunakan buku kunci identifikasi nematoda sehingga memerlukan waktu yang relatif lebih lama. Oleh karena itu diperlukan pengembangan metode deteksi dan identifikasi NPA yang dapat mempersingkat waktu dan digunakan oleh semua kalangan. Salah satu alternatif metode identifikasi NPA ialah menggunakan teknik molekuler. Hikmia et al. (2012) melaporkan bahwa identifikasi NPA menggunakan metode molekuler terbilang efektif dan efisien.

Identifikasi NPA berdasarkan karakter molekuler dapat dilakukan dengan metode DNA barcoding. Teknik identifikasi DNA barcoding dapat menyediakan sebuah "barkode biologi" dari urutan pendek DNA yang distandarisasi untuk mengenali suatu spesies (Hajibabaei et al. 2006). Gen yang digunakan dalam metode DNA barcoding berasal dari organel mitokondria nematoda. Gen tersebut dikenal sebagai cytochrome oksidase subunit 1 (CO1).
Gen CO1 merupakan gen barcode yang paling banyak ditemukan pada hewan (Ratnasingham dan Hebert 2007). Fragmen pendek CO1 dapat digunakan sebagai penanda variasi yang secara akurat dapat mengidentifikasi berbagai macam hewan sampai tingkat spesies (Waugh 2007) dan merekonstruksi filogenetika pada cabang evolusitingkat spesies(Palumbi 1996). Deteksi dan identifikasi nematoda menggunakan DNA barcoding memiliki akurasi yang tinggi sehingga dapat dilakukan pada berbagai stadia nematoda.

Pemilihan tanaman bit dalam penelitian ini karena bit merupakan tanaman yang banyak dicari dan diminati oleh masyarakat seiring dengan kesadaran masyarakat terhadap kesehatan tubuhnya. Tanaman bit merupakan salah satu tanaman yang mengandung antioksidan tinggi sehingga diyakini sebagai anti kanker dan anti tumor. Namun produksi tanaman bit belum maksimal. Salah satu hal yang menyebabkan produksi belum maksimal ialah adanya serangan nematoda puru akar (NPA) Meloidogyne spp. Identifikasi NPA pada tanaman bit di Indonesia saat ini baru dilakukan berdasarkan karakter morfologi. Draycott (2006) melaporkan terdapat delapan spesies NPA yang ditemukan berdasarkan karakter morfologi, yaitu $M$. arenaria, $M$. hapla, M. incognita, M. javanica, M. naasi, M. thamesi, M. chitwoodi, dan M. fallax. Hasil identifikasi berdasarkan karakter morfologi tersebut perlu diidentifikasi lebih lanjut berdasarkan karakter molekuler. Penelitian ini bertujuan untuk mengidentifikasi NPA yang berasosiasi pada tanaman bit berdasarkan sikuen gen $\mathrm{CO} 1$ Meloidogyne. 


\section{BAHAN DAN METODE}

\section{Lokasi penelitian dan penentuan sampel}

Pengambilan sampel dilakukan secara purposive sampling, yaitu mengambil sampel tanaman bit yang bergejala puru akar pada umbi dan perakaran di sentra pertanaman bit Desa Gunung Batu, Jolok, Sindanglaya, Ciherang, Kecamatan Cipanas, Kabupaten Cianjur, Jawa Barat. Sampel kemudian diletakkan di cool box, dan dibawa ke Laboratorium Nematologi Tumbuhan, Fakultas Pertanian, IPB.

\section{Pembuatan Preparat Pola Perineal}

Prosedur pembuatan preparat pola perineal ini mengacu pada prosedur GilchristSaavedra (1997). Akar dan umbi yang diduga terinfeksi nematoda dibedah pada bagian yang menunjukkan gejala puru sehingga didapatkan nematoda betina dewasa. Kutikula pada bagian leher nematoda betina dipotong, dan tubuh nematoda ditekan dengan kuat hingga isi tubuhnya keluar. Bagian tubuh yang tersisa ditetesi asam laktat $45 \%$ untuk menghilangkan isi tubuh yang masih melekat pada kulit. Selanjutnya, tubuh nematoda dipotong pada bagian posteriornya (pola parenial) dan diletakan di atas gelas objek. Bagian muka pola parenial diarahkan menghadap ke atas, kemudian ditutup dengan gelas penutup. Pengamatan sidik pantat menggunakan mikroskop compound dengan mengacu pada A guide to the four most common species of root knot nematodes (Meloidogyne species) with a pictorial key (Eisenback et al. 1981).

\section{Ekstraksi DNA Nematoda}

Ekstraksi DNA nematoda Meloidogyne spp. menggunakan metode Holterman et al. (2006). Sebanyak 3-5 ekor nematoda betina dicampur dengan $25 \mu \mathrm{L}$ air bebas nuklease dan $25 \mu \mathrm{L}$ bufer ekstraksi $(200 \mathrm{mM} \mathrm{NaCl}, 200 \mathrm{mM}$ Tris-HCL pH 8, 1\% 2-mercaptoethanol, dan $800 \mu \mathrm{g} \mathrm{mL}^{-1}$ Proteinase K). Suspesi DNA divorteks selama 1 menit dan diinkubasi pada suhu $65{ }^{\circ} \mathrm{C}$ selama $1.5 \mathrm{jam}$, serta $99{ }^{\circ} \mathrm{C}$ selama 5 menit dengan mesin PCR. Suspensi DNA disimpan pada suhu $-20{ }^{\circ} \mathrm{C}$ sampai akan digunakan sebagai template dalam PCR.
Amplifikasi gen CO1 Nematoda Puru Akar Amplifikasi gen CO1 NPA menggunakan primer spesifik $M$. incognita CO1SIF (5'-GCCTGCATTTGGTTAG-'3) dan CO1SIR (5'-TCAAACCAGTCCT-'3), $M$. arenaria CO1SAF (5'-GGGTACTGGATG AACATTA-‘3) dan CO1SAR (5'-ACTT CAGGATGACCAAA-'3). Setiap reaksi PCR terdiri atas $12.5 \mu \mathrm{L} 2 \mathrm{x}$ Go Taq ${ }^{\circledR}$ Green Master mix (Promega), $1 \mu \mathrm{L}$ primer forward $10 \mu \mathrm{M}$, $1 \mu \mathrm{L}$ primer reverse $10 \mu \mathrm{M}, 2 \mu \mathrm{L}$ templat DNA, dan $8.5 \mu \mathrm{L}$ air bebas nuklease sehingga volume menjadi $25 \mu \mathrm{L}$. Program PCR terdiri atas tahapan pradenaturasi pada suhu $94{ }^{\circ} \mathrm{C}$ selama 4 menit, 30 siklus untuk denaturasi pada suhu $94{ }^{\circ} \mathrm{C}$ selama 1 menit, penempelan primer pada suhu $55^{\circ} \mathrm{C}$ selama 1 menit, dan ekstensi DNA baru pada suhu $72{ }^{\circ} \mathrm{C}$ selama 2 menit. Selanjutnya ekstensi akhir pada $72{ }^{\circ} \mathrm{C}$ selama 10 menit dan penyimpanan pada suhu $4{ }^{\circ} \mathrm{C}$. Produk PCR dielektroforesis dalam gel agarosa $1 \%$ dengan bufer TAE dan visualisasi dengan $U V$ transiluminator.

\section{Analisis Perunutan Nukleotida dan Rekonstruksi Pohon Filogenetika}

Perunutan nukleotida dilakukan dengan mengirimkan fragmen DNA hasil amplifikasi ke PT. Genetika Science Indonesia untuk dilakukan perunutan nukleotida. Hasil perunutan dianalisis menggunakan program basic local alignment search tool (BLAST) dalam situs national center for biotechnology information (NCBI). Runutan nukleotida yang diperoleh kemudian dianalisis menggunakan penyejajaran berganda ClustalW pada perangkat lunak Bioedit sequence alignment editor versi 7.0.3.5. Hubungan kekerabatan antar isolat dikonstruksi menggunakan perangkat lunak molecular evolutionery genetic analysis (MEGA) versi 6.06 dengan bootstrap 1000 kali ulangan.

\section{HASIL}

\section{Gejala Penyakit}

Tanaman bit yang terserang nematoda puru akar memiliki gejala berupa tanaman kerdil, daun menguning, dan layu. Gejala penyakit pada tajuk tanaman di lahan pertanian sulit 
dibedakan antara tanaman yang terserang dengan tanaman sehat. Hal ini dikarenakan pada saat pengambilan sampel, tajuk tanaman sehat dan terserang tidak menunjukkan adanya infeksi NPA. Tanaman yang terlihat sehat pun dapat terinfeksi NPA. NPA juga menyebabkan terjadinya pembentukan akar cabang yang cukup banyak pada bagian perakaran yang disebut akar berambut (hairy root) (Gambar 1).

\section{Pengamatan Pola Perineal}

Berdasarkan hasil pengamatan pola perineal NPA asal Desa Gunung Batu, Jolok, Sindanglaya, dan Ciherang Kecamatan Cipanas, Kabupaten Cianjur Jawa Barat, ditemukan dua spesies Meloidogyne, yaitu $M$. arenaria dan $M$. incognita (Gambar 2). Nematoda $M$. incognita memiliki lengkung dorsal yang tinggi dan menyempit sedangkan pada bagian luarnya sedikit melebar dan agak mendatar (Gambar 2a dan 2c). Nematoda $M$. arenaria memiliki lengkung dorsal yang rendah dan bulat di sekitar garis lateral. Bagian lengkung stria bercabang di dekat garis lateral dengan bagian stria atas lebih mendatar (Gambar 2b dan 2d).

\section{Distribusi Nematoda Puru Akar}

Hasil pengamatan pola perineal nematoda betina dewasa menunjukkan bahwa pada semua lokasi pengamatan ditemukan dua spesies Meloidogyne, yaitu M. arenaria dan $M$. incognita. Jumlah $M$. arenaria yang ditemukan di Desa Jolok, Gunung Batu, Sindanglaya, dan Ciherang secara berturutturut ialah 5, 2, 60, dan 7 individu, sedangkan $M$. incognita yang ditemukan pada masingmasing desa berjumlah 45, 30, 30, dan 59 individu (Tabel 1). Lokasi pengambilan sampel yang terletak di bawah kaki Gunung Pangrango memiliki ketinggian $1.110 \mathrm{~m}$ dpl. Suhu di lokasi tersebut berkisar antara $16^{\circ} \mathrm{C}$ hingga $27^{\circ} \mathrm{C}$ dan kelembaban berkisar antara $87-93 \%$.

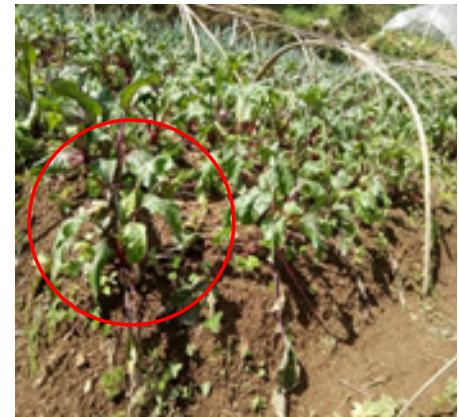

a

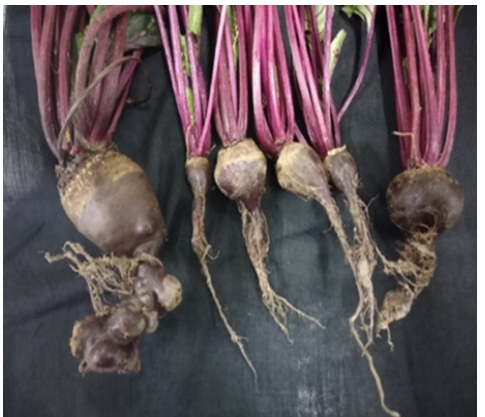

b

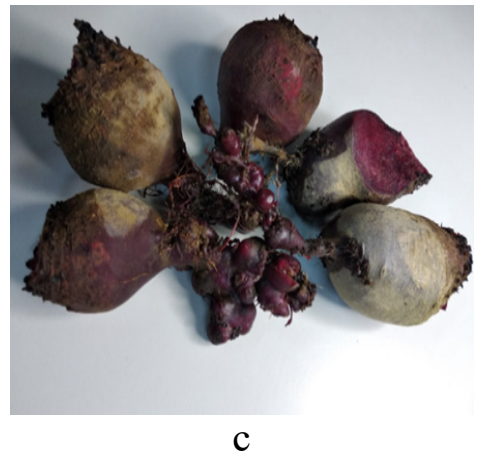

C

Gambar 1 Variasi gejala penyakit yang disebabkan oleh Meloidogyne pada pertanaman dan umbi. a, Tanaman layu dan menguning; b, Akar bercaban dan berambut (hairy root); dan c, Malformasi pada umbi.

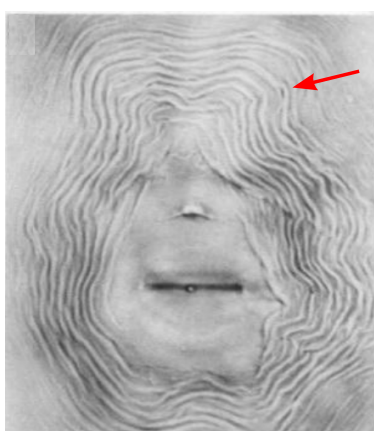

a

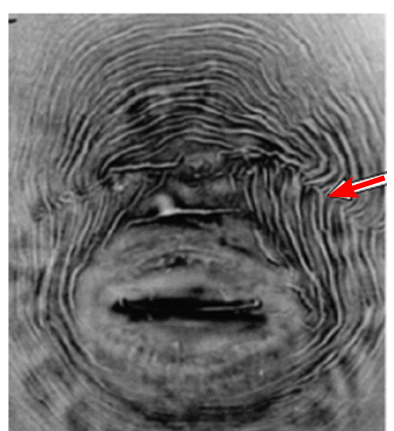

b

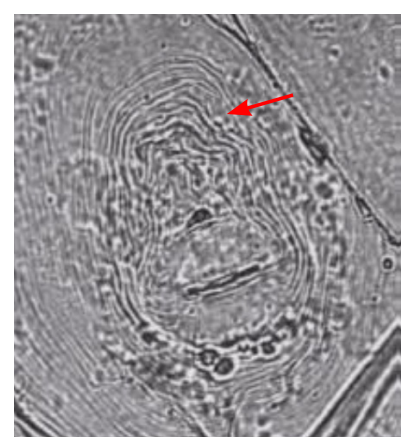

c

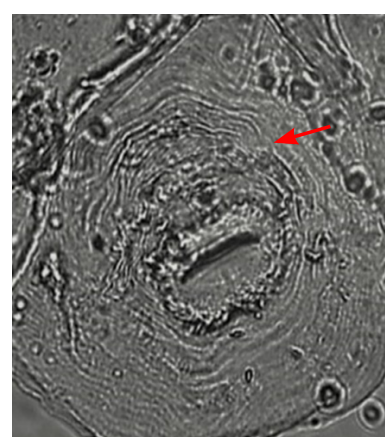

d

Gambar 2 Pola perineal Meloidogyne spp. a, M. incognita; dan b, M. arenaria berdasarkan Eisenback et al. 1981; sedangkan c, M. incognita; dan d, M. arenaria hasil identifikasi. 
Identifikasi Molekuler Meloidogyne spp.

Hasil amplifikasi gen CO1 pada sampel NPA menunjukkan hasil positif dan didapatkan pita DNA berukuran \pm 360 untuk $M$. arenaria dan \pm 326 untuk M. incognita (Gambar 3). Analisis kesejajaran menunjukkan bahwa M. arenaria asal Indonesia homologi $100 \%$ dengan isolat $M$. arenaria asal Argentina dan Amerika Serikat (Tabel 2). Analisis filogenetika menunjukkan bahwa isolat $M$. arenaria asal Indonesia satu kelompok dengan isolat $M$. arenaria asal Argentina dan Amerika Serikat (Gambar 4).

Berdasarkan pada analisis kesejajaran, $M$. incognita asal Indonesia homologi dengan isolat asal Cina, Amerika Serikat, Inggris, dan Vietnam dengan tingkat homologi sebesar $100 \%$ (Tabel 3). Hal ini didukung juga dengan analisis filogenetikanya (Gambar 5).

\section{PEMBAHASAN}

Meloidogyne spp. merupakan nematoda penyebab penyakit tanaman paling dikenal di seluruh dunia karena gejala pada bagian akar sangat menonjol dan spesifik, yaitu menyebabkan puru pada akar tanaman. Hingga saat ini sekitar 100 spesies Meloidogyne yang

Tabel 1 Jumlah nematoda yang ditemukan pada lokasi pengambilan sampel

\begin{tabular}{lcc}
\hline Lokasi & M. arenaria & M. incognita \\
\hline Desa Jolok & 5 & 45 \\
Desa Gunung Batu & 2 & 30 \\
Desa Sindanglaya & 60 & 30 \\
Desa Ciherang & 7 & 59 \\
\hline
\end{tabular}

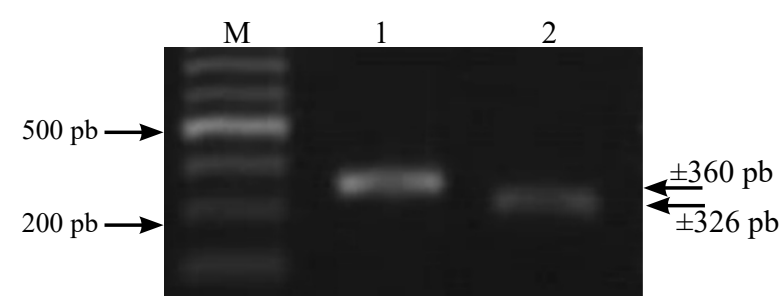

Gambar 3 Hasil amplifikasi DNA $M$. incognita dengan primer CO1SIF dan CO1SIR, serta $M$. arenaria dengan primer CO1SAF dan CO1SAR. M; Marker 100 pb (Thermoscientific, US); 1, M. arenaria; dan 2, M. incognita. telah dideskripsikan (Mitkowski dan Abawi 2003). Sebanyak enam spesies diantaranya menjadi perhatian utama karena dapat menurunkan produksi tanaman dan merugikan secara ekonomi, yaitu $M$. incognita, $M$. javanica, M. arenaria, M. hapla, M. chitwoodi dan M. fallax (Adam et al. 2007).

Gejala serangan NPA pada umbi tanaman bit sulit diketahui dari permukaan tanah. Namun demikian, pada umumnya tanaman bit yang terserang NPA memiliki tangkai daun yang lebih panjang dengan warna daun hijau atau kuning tergantung tingkat serangan. Tanaman yang terserang cenderung kerdil dan layu karena akarnya kurang berkembang dan memiliki serat lebih banyak. Tanaman yang terinfeksi NPA memiliki gejala khas berupa bintil yang disebut dengan puru pada bagian akar dan umbi. Puru yang terbentuk pada bagian umbi dapat menyebabkan malformasi umbi. Perubahan bentuk ini akan memengaruhi kualitas umbi yang dihasilkan sehingga dapat menyebabkan kerugian (Jayanti 2011). Puru yang terbentuk memiliki ukuran yang beragam bergantung pada jenis tanaman, jenis nematoda, dan jumlah populasi nematoda yang terdapat di dalam puru tersebut. Terbentuknya puru akar merupakan akibat pertambahan ukuran sel menjadi sel raksasa (hipertrofi) dan pertambahan jumlah sel secara cepat (hiperplasia) (Yulianti 2017).

Keberadaan NPA di pertanaman didukung oleh keadaan lingkungan yang sesuai bagi pertumbuhan dan perkembangbiakan. Keadaan lingkungan di Desa Gunung Batu, Jolok, Sindanglaya, Ciherang, Kecamatan Cipanas, Kabupaten Cianjur, Jawa Barat memiliki suhu berkisar antara $16^{\circ} \mathrm{C}$ hingga 27 ${ }^{\circ} \mathrm{C}$ dan kelembaban berkisar antara 87-93\%. Kondisi tersebut sesuai bagi pertumbuhan dan perkembangan NPA. Suhu optimum bagi pertumbuhan Meloidogyne spp. ialah 15-25 ${ }^{\circ} \mathrm{C}$. M. hapla dapat menginfeksi inangnya pada suhu $5-35{ }^{\circ} \mathrm{C}$ (Ferris 2008). Telur $M$. graminicola menetas pada suhu optimum antara $25-30{ }^{\circ} \mathrm{C}$ (Ravinndra et al. 2017).

Nematoda puru akar yang berasosiasi dengan tanaman bit di Cipanas, Jawa Barat adalah $M$. arenaria (2-40 ekor) dan $M$. 
Tabel 2 Tingkat homologi runutan nukleotida dan asam amino M. arenaria asal Cipanas dengan spesies dari negara lain yang ada di GenBank

\begin{tabular}{lcccc}
\hline Spesies & Negara & No Aksesi & \multicolumn{2}{c}{ Homologi (\%) } \\
\cline { 3 - 5 } & & & Nukleotida & Asam amino \\
\hline Meloidogyne arenaria & Indonesia & LC488827 & 100 & 100 \\
M. arenaria & Argentina & KM491204 & 100 & 100 \\
M. arenaria & Argentina & KM491203 & 100 & 100 \\
M. arenaria & Argentina & KM491202 & 100 & 100 \\
M. arenaria & Argentina & KM491201 & 100 & 100 \\
M. arenaria & Argentina & KM491200 & 100 & 100 \\
M. arenaria & Argentina & KM491199 & 100 & 100 \\
M. arenaria & Amerika Serikat & MH128444 & 100 & 100 \\
M. arenaria & Jerman & MH399814 & 63.2 & 43.3 \\
M. arenaria & Vietnam & KU360143 & 54.5 & 29.1 \\
H. glycines & Amerika Serikat & MK093147 & 65.7 & 58.3 \\
\hline
\end{tabular}

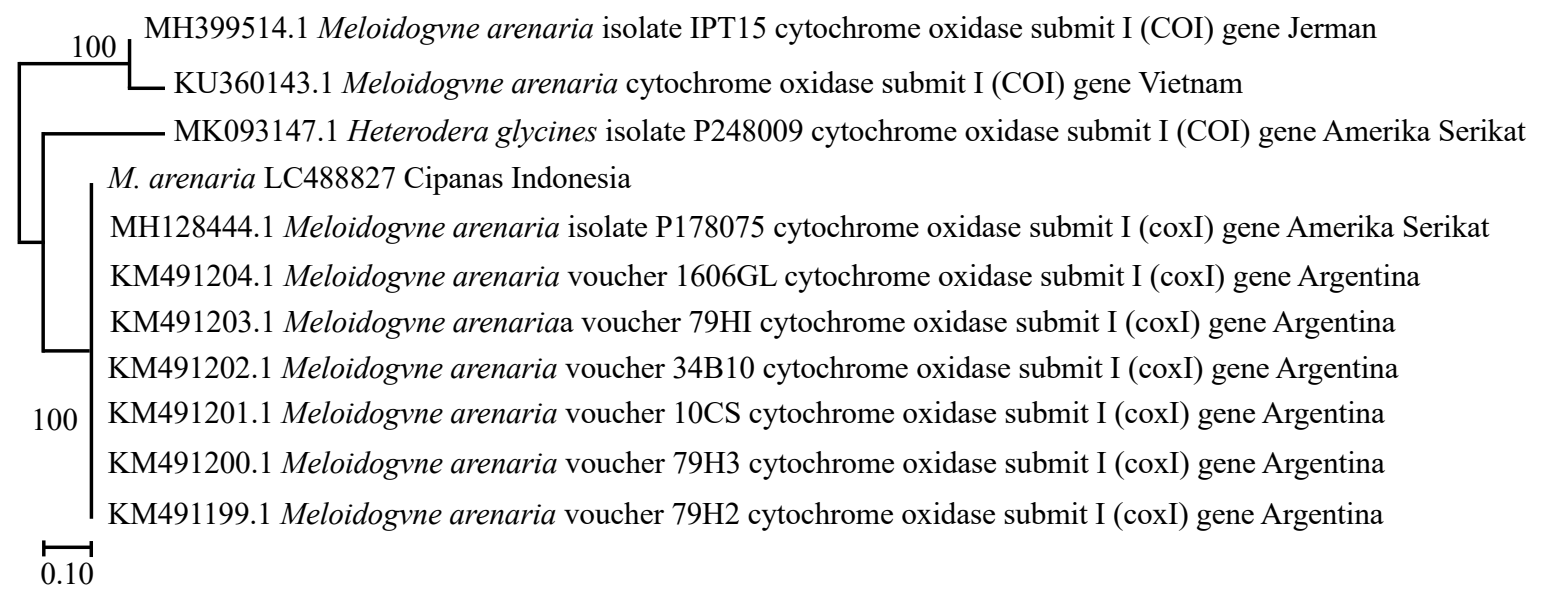

Gambar 4 Analisis filogenetika M. arenaria asal Cipanas terhadap spesies.arenaria dari negara lain yang terdapat pada Genbank berdasarkan runutan nukleotida menggunakan program Mega v 6.06 dengan pendekatan maximum likelihood bootstrap 1000×.

Tabel 3 Tingkat homologi runutan nukleotida dan asam amino M.incognita asal Cipanas dengan spesies dari negara lain yang ada di GenBank

\begin{tabular}{lcccc}
\hline \multicolumn{1}{c}{ Spesies } & Negara & No Aksesi & \multicolumn{2}{c}{ Homologi (\%) } \\
\cline { 3 - 5 } & & & Nukleotida & Asam amino \\
\hline Meloidogyne incognita & Indonesia & Na & 100 & 100 \\
M. incognita & Cina & MH743221 & 100 & 100 \\
M. incognita & Cina & MH743220 & 100 & 100 \\
M. incognita & Cina & MH743219 & 100 & 100 \\
M. incognita & Amerika Serikat & MH128429 & 100 & 100 \\
M. incognita & Amerika serikat & MH128428 & 100 & 100 \\
M. incognita & Vietnam & MH332670 & 100 & 100 \\
M. incognita & Inggris & KU517167 & 100 & 100 \\
H. glycines & Amerika Serikat & MK093147 & 71.6 & 47.5 \\
\hline
\end{tabular}

Na: belum ada nomor aksesi 


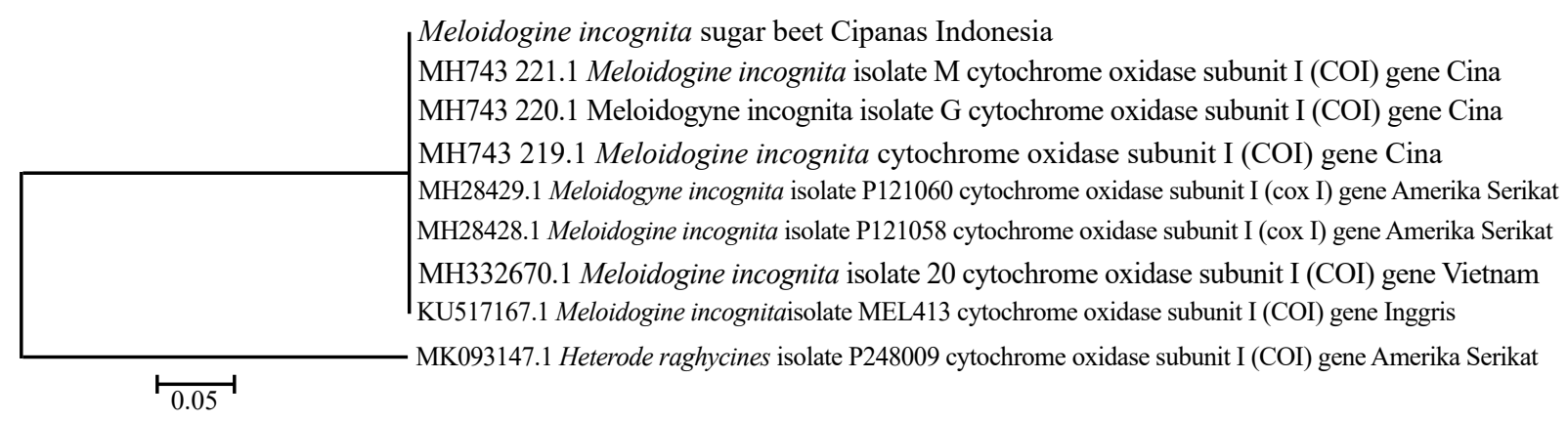

Gambar 5 Analisis filogenetika M. incognita asal Cipanas terhadap spesies dari negara lain yang terdapat pada Genbank berdasarkan runutan nukleotida menggunakan program Mega $\mathrm{V}$ 6.06 dengan pendekatan maximum likelihood bootstrap 1000×.

incognita (20-70 ekor). Hasil identifikasi morfologi berdasarkan pola perenial nematoda betina telah dikonfirmasi dengan PCR menggunakan primer spesifik mtCO1 dan sikuensing menunjukkan bahwa spesies nematoda $M$. arenaria asal Indonesia berkerabat dekat dengan spesies asal Argentina dan Amerika Serikat, sedangkan $M$. incognita berkerabat dekat dengan $M$. arenaria asal Cina, Amerika Serikat, Vietnam, dan Inggris. Menurut Khan et al. (2012), nilai tingkat kesamaan (homologi) lebih besar dari $90 \%$ pada perunutan nukleotida antara satu nematoda dengan nematoda lainnya, maka dapat dikatakan merupakan spesies yang sama dan tidak ada perbedaan genetik walaupun terdapat pada komoditas yang berbeda.

\section{DAFTAR PUSTAKA}

Adam MAM, Philips MS, Blok VC. 2007. Molecular diagnostic key for identification of single juveniles of seven common and economically import species of rootknot nematode (Meloidogyne spp.). Plant Pathology. 56:190-197. DOI: https://doi. org/10.1111/j.1365-3059.2006.01455.x.

Draycott AP. 2006. Sugar Beet. Oxford (UK): Blackwell Publishing Ltd. DOI: https:// doi.org/10.1002/9780470751114.

Eisenback JD, Hirschmann H, Sasser JN, Triantaphyllou AC. 1981. A Guide to the Four Most Common Species of RootKnot Nematodes (Meloidogyne species) with a Pictorial Key. Washington (US): Department of Plant Pathology.
Ferris H. 2008. Meloidogyne hapla [internet]. [diunduh 2018 Agustus 10]. Tersedia pada: http://www.nematode.unl.edu/mhap.htm.

Hajibabaei M, Daniel J, Burn J, Hallwachs W, Hebert P. 2006. DNA Barcodes distinguish spesies of tropical Lepidoptera. PNAS. 4(103):968-971. DOI: https://doi. org/10.1073/pnas.0510466103.

Hikmia Z, Supramana, Suastika G. 2012. Identifikasi penyakit umbi bercabang pada tanaman wortel di Jawa Timur. J Fitopatol Indones. 8(3):73-78. DOI: https://doi. org/10.14692/jfi.8.3.73.

Holterman M, Wurff VDA, Elsen VDS, Megan VH, Bongers T, Holovachov O, Bakker J, Helder J. 2006. Phylum-wide analysis of SSU rDNA reveals deep phylogenetic relationships among nematodes and accelerated evolution toward crown clades. Mol Biol Evol. 23(9):1792-800.DOI: https://doi.org/10.1093/molbev/msl044.

Jayanti W. 2011. Identifikasi spesies nematoda puru akar (Meloidogyne spp.) pada umbi kentang asal Pengalengan dan Kertasari, Kabupaten Bandung, Jawa Barat [skripsi]. Bogor (ID): Institut Pertanian Bogor.

Khan MR, Handoo ZA, Rao U, Rao SB, Prasad JS. 2012. Observations on the foliar nematode, Aphelenchoides besseyi, infecting tuberose and rice in India. $J$ Nematol. 44(4):391-398.

Mitkowski NA, Abawi GS. 2003. Rootknot nemoatodes. The Plant Heath Instructor. DOI: https://doi.org/10.1094/ PHI-I-2003-0917-01. 
Palumbi SR. 1996. Nucleic acid II: the polymerase chain reaction. Di dalam: Molecular Systematic. Hillis DM, Moritz, Mable BK, editor. hal 205-247.

Rahman RM, Munif A, Kurniawati F. 2018. Deteksi dan identifikasi nematoda Aphelenchoides besseyi pada lima varietas padi. J Fitopatol Indones. 14(12):39-46. DOI: https://doi.org/10.14692/jfi.14.2.39.

Ratnasingham S, Hebert PDN. 2007. Barcoding bold: The barcode of life data system (www.barcodinglife.org). Mol Ecol Notes. 7:355-364. DOI: https://doi. org/10.1111/j.1471-8286.2007.01678.x.

Ravinndra H, Sehgal M, Narasimhamurthy HB, Jayalakshmi K, Khan HSI. 2017. Rice root-knot nematode (Meloidogyne graminicola) an emerging problem. Int
J Curr Microbiol App Sci. 6(8):31433171. DOI: https://doi.org/10.20546/ ijcmas.2017.608.376.

Gilchrist-Saavedra L. 1997. Practical Guide to The Identification of Selected Diseases of Wheat And Barley. Mexico (MX) CIMMYT.

Waugh J. 2007. DNA barcoding in animal species: Progres potential and pitfall. Bio Essay. 29(2):188-197. DOI: https://doi. org/10.1002/bies.20529.

Yulianti E. 2017. Populasi dan tingkat serangan nematoda puru akar (Meloidogyne spp.) pada beberapa tingkat umur tanaman jambu biji di PT Nusantara Tropical Farm [skripsi]. Lampung (ID): Universitas Lampung. 